Copyright (C) 2018 by Academic Publishing House Researcher

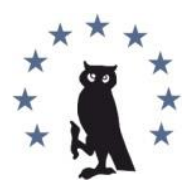

Published in the Russian Federation

European Researcher. Series A

Has been issued since 2010.

ISSN 2219-8229

E-ISSN 2224-0136

2018, 9(4): 298-306

DOI: $10.13187 / \mathrm{er} .2018 .4 .298$

www.erjournal.ru

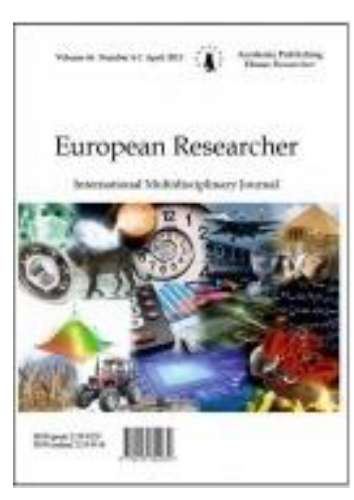

\title{
Opportunities and Challenges Facing Bosnian High-School EFL Learners
}

\author{
Fatima Kovačević a , Amna Brdarević-Čeljo a, Senad Bećirović a , ${ }^{*}$ \\ ${ }^{\text {a }}$ International Burch University, Bosnia and Herzegovina
}

\begin{abstract}
The importance of learning English as a second or foreign language has been globally recognized, as its presence is plainly evident in diverse areas, in the area of business and science in particular (Schütz, 2005). Thus, as a global lingua franca, the English language is taught as the first foreign language in non-English-speaking countries around the world, and likewise it is fairly widespread as a compulsory course in elementary and secondary schools in Bosnia and Herzegovina. According to the curriculum of the Ministry of Education, Science and Youth (Ministry of Education, 2016), the expected level of English language proficiency that students need to achieve at the end of their secondary education is B2+ (CEFR, 2001). With this in mind, this paper primarily aims to determine whether Bosnian secondary-school students reach the expected B2+ level of English language proficiency as well as whether there is any significant difference between female and male students in that respect. In order to gain a better insight into the grading practices, a correlation between the students' proficiency level and the English language grade they obtain at the end of the academic year was also explored.
\end{abstract} GPA.

Keywords: English language proficiency, high school students, foreign language learning,

\section{Introduction}

With the largest number of second or foreign-language speakers in the world (Simons, Fennig, 2018) and that is 1.6 billion (Crystal, 2012, 2015), English is certainly the most dominant language in different foreign language contexts. It is thus taught as a foreign language all over the world through formal education and different courses in foreign language schools, starting from kindergartens to elementary and secondary schools and then being also one of the obligatory or elective courses at various universities. However, it is also acquired informally, through watching movies and listening to music in English, as well as through different informal technologyinvolving activities, which seems to further confirm the strong position of a global lingua franca that it has held for many years.

In Bosnia and Herzegovina, English is taught as the first foreign language from the first grade of elementary schools in the Sarajevo Canton or the third grade in other cantons (Ministry of Education, 2016). Thus, Bosnian students are exposed to English through formal education for a rather long period of time spaning from eleven to thirteen years. In secondary schools, students have two, three or four classes per week, depending on the type of school they attend (vocational school, gymnasiums (general department) and gymnasiums (language department) respectively).

\footnotetext{
* Corresponding author

E-mail addresses: senad.becirovic@ibu.edu.ba (S. Bećirović)
} 
The official English language curriculum followed in secondary schools clearly sets out goals and tasks for students to achieve during each school year. Thus, according to the Ministry of Education (Ministry of Education, 2016), students' expected English language proficiency level is $\mathrm{B} 2+/ \mathrm{C} 1$ if English is taught as a first foreign language in gymnasiums, while it is B1+ if English is learned as a second foreign language. $\mathrm{B} 2+/ \mathrm{C} 1$ is required in some schools or departments since these students are exposed to more English language classes and their focus is on language learning in comparison to the other subjects. Since no research whatsoever has been conducted so far to show how potentially effective English language teaching and learning in the Bosnian EFL context is and whether the curriculum expectations are met in reality, this paper aims at determining the level of English language proficiency of final-grade students at a secondary school in Sarajevo and it also aims to observe whether the achieved results meet the expectations raised in the officially approved curricula.

The main reason lying behind such research is to get a better insight into the situation with English language proficiency and to try to draw relevant attention to the importance of English language proficiency testing especially at the end of students' high school education.

\section{Literature review}

Extensive research on foreign language teaching, and English language teaching and learning in particular, has been conducted in different EFL contexts, including various aspects such as foreign language learning motivation, types of teaching and learning methods, factors influencing foreign language acquisition as well as many others (Brown, 1994; Crystal, 1997, 2003; Lambert, Gardner, 1972; Krashen, 1987; Ortega, 2009; Rost, 2006). The importance of learning English as a foreign language is also reflected in the fact that this is a mandatory subject in as many as 14 European countries or regions within countries, including primary and secondary schools (Baidak, et al., 2012) and the improvement of the quality and effectiveness of language learning has become one of the key goals of the European Educational and Training Framework for Education and Training "ET 2020" (Baidak et al., 2012). A large amount of research studies devote close attention to students as individuals and focuses on their personal interests and needs in terms of foreign language learning, including their age, gender, motivation as well as methods and learning strategies (Dornyei, 1994; Horwitz, 1987).

In addition to that, a significant wealth of research also deals with factors influencing the process of English language learning, but there are few studies focusing on the students' achieved language proficiency and the factors impacting it. Namely, Makewa, et al. (2013) conducted research in secondary schools in Dodoma, Tanzania, which investigated the perceived English language proficiency of 300 secondary school students, 131 female and 169 male participants. The factors affecting their English language proficiency that were taken into consideration and measured were learning resources, classroom activities, anxiety, attitude, and motivation. The results showed that their perceived English language speaking skills were on an average level. Furthermore, a statistically significant correlation between the factors influencing their English language knowledge and their perceived proficiency was found. It was concluded that attitude, classroom activities and motivation were the most significant factors influencing the students' English language proficiency. Finally, the authors suggested that further research needed to be conducted in order to obtain a better insight into the students' real proficiency level since the questionnaire was based only on the students' self-perceptions. Sijali (2017) also strived to measure the proficiency level of 529 high school students and to determine the impacting factors. The findings indicated that the students' knowledge of the English language was not on an enviable level, but the male participants achieved better results than the female participants and the privateschool students performed better than the public-school students.

\subsection{The present study}

To our knowledge, no similar research was conducted in the Bosnian EFL context. Some steps were taken in the direction of improving the process of English language teaching and a plan of external testing was adopted in 2013 and implemented in primary schools in Sarajevo, Zenica and other cities, where the students' knowledge in the field of mathematics, Bosnian/Croatian/Serbian and the first foreign language was examined. The main aim of this testing was to show that "students know English at the predefined level of morphology, semantics, syntax and lexis, to use certain vocabulary, and to deal with different types of tasks". 
The conducted proficiency test consisted of reading, vocabulary, grammar and communication skills. The results of external testing conducted in the 2012/2013 school year including 2.583 finalyear students from 65 primary school in the Canton of Sarajevo and 221 students outside the Canton of Sarajevo showed that the mean for the English language was $M=8.26$ (the maximum number of points was 10). The overall results pointed to the fact that the external testing scores are in line with the achieved scores obtained in English language classes at the end of their nine-year education (Ministry of Education, 2016).

Moreover, Ivošević et al. (2013) evaluated the application of curricula in 5 groups of related professions in SSO B\&H and examined students', teachers' and parents' attitudes towards learning and teaching in high schools in general. The study suggested that no major changes related to the curriculum had been made lately and that the students, parents, and teachers believed that the existing curricula and programs were not flexible and needed adjustments and changes, as well as that the existing modular curriculum is preferred over the traditional one. Depending on the school, the participants' opinions were divided on the specific teaching content and practical application of the acquired knowledge, as well as the introduction of elective courses.

As for the process of learning, English language learning in particular, many research studies primarily focused on the use of different types of learning strategies (Bećirović et al., 2017; Bećirović et al., 2018; Brdarević-Čeljo, Asotić, 2017), whereas some studies investigated different factors impacting students' proficiency in primary and high schools in Sarajevo and other cities in B\&H (Bećirović, Podojak, 2018; Delić et al,, 2018; Habibić, Dubravac, 2016, Rizvić, Bećirović, 2017; Tankosic, Dubravac, 2016). For instance, Tankosić and Dubravac (2016) investigated the assessment of Bosnian EFL learners' knowledge by means of two different measures, a test and a writing assignment. They analyzed and compared the results of the test and writing assignments given to the students and also conducted interviews with the professors. The results showed that the focus is placed more on accuracy than fluency as well as on explicit rather than implicit knowledge. Furthermore, Delić et al. (2018) analyzed the effects of grade level and gender on the foreign language learning process in Bosnian high schools and the findings indicated significant differences between male and female respondents in foreign language learning. On the other hand, no significant differences were measured between students of different grade levels. The aforementioned research aimed at providing a deeper insight into the difficulties the students face in the process of English language learning.

Thus, this research might fill a gap in the existing research and show whether any discrepancy exists between the English language curriculum goals and expectations, on the one hand, and real English language proficiency of the fourth grade secondary school students, on the other hand. Since, to our knowledge, no similar research has been conducted in Bosnia and Herzegovina, this paper presents an attempt to shed some light on the issue. Thus, the present research is guided by the following research questions:

RQ1: Do the secondary school students reach B2+ level at the end of their secondary education?

RQ2: Is there a correlation between the students' English language proficiency and their English language grade?

RQ3: Is there a statistically significant difference between female and male students' English language proficiency?

RQ4: What are the students' perceptions about their English language course in the school?

H1: Secondary school students are expected to reach B2+ level of English language proficiency at the end of their secondary school education (Ministry of Education, 2016).

H2: There is a significant correlation between the students' English language proficiency and their English language grade.

Ho3: There is no statistically significant difference between male and female students in regards to their English language proficiency level. 


\section{METHODS}

3.1 Participants

The mixed method design was employed within this study. The respondents were 58 fourthgrade secondary-school Bosnian students, out of whom 38 (65.5\%) respondents were female and $20(34.5 \%)$ male. As for their general success at school, 8 respondents were good, 27 very good, and 23 were excellent (Table 2). In regards to their English language grade, 8 students obtained $\mathrm{C}$ ('good'), 29 B ('very good'), and 21 A ('excellent'). A detailed description of the participants is provided in Table 1.

Table 1. Demographic statistics

\begin{tabular}{llcc}
\hline & & N & Percent \\
\hline \multirow{2}{*}{ Gender } & Female & 38 & 65.5 \\
& Male & 20 & 34.5 \\
Overall success at school & Excellent (A) & 23 & 39.7 \\
& Very good (B) & 27 & 46.6 \\
\multirow{2}{*}{ English language grade } & Good (C) & 8 & 13.8 \\
& Excellent (A) & 21 & 36.2 \\
& Very good (B) & 29 & 50 \\
TOTAL & Good (C) & 8 & 13.8 \\
\hline
\end{tabular}

3.2. Measures and procedures

All the respondents completed a Full placement test, with the permission from the Mind Series, Macmillan Education website. The test, which was completely anonymous, consisted of two parts. The first part contained demographic data, including gender, year, GPA, English language GPA and some open ended questions. The second part contained the Full Placement Test consisting of 60 multiple-choice questions, three reading parts, and three writing tasks. Taking into consideration that it was necessary to allocate a minimum of 60 minutes for the entire test, it was necessary for the instrument to be reduced and it ultimately consisted of 60 multiple-choice questions in the grammar and vocabulary section, and included one reading and one writing section. In regards to the test scoring, the original test maximum score was 100 , where the levels are settled from essentials to Master Mind 2 which are from pre-A1 to B2/C1 CEFR level. However, since it was necessary for this test to be reduced, the scores for different levels were also adjusted as it can be seen in Table 2.

Table 2. Full Placement Test grading scale

\begin{tabular}{lll}
\hline Number of points & Full Placement Test Level & CEFR Level \\
\hline 0-6.5 & Essentials & Pre-A1 \\
$7-18$ & openMind 1 & A1 \\
$18.5-33$ & opendMind 2 & A2 \\
$33 \cdot 5-48$ & opendMind 3 & B1 \\
$48.5-66$ & masterMind 1 & B1/B2 \\
$66.5-73$ & masterMind 2 & B2/C1 \\
\hline
\end{tabular}




\subsection{Results}

Do secondary school students reach B2+ level at the end of their secondary education?

In regards to the students' English language proficiency level, the result mean value for all the participants was $M=41.59$ and the standard deviation $S D=13.64$. The overall test results show that only 2 (4\%) out of 58 students met the criteria for B2+ level of English language proficiency $(M=41.59$,$) . The results are based on their total sum of the test scores, including vocabulary,$ grammar, reading, and writing. Most of the respondents, namely 21 (38\%) of them were at B1 level, followed by 18 respondents (31 \%) whose English level proficiency was between B1 and B2, 14 respondents (22 \%) who achieved A2 level, and finally there were also 3 (5\%) respondents whose total sum of points indicated that they reached A1 level (see Graph 1). The minimal score achieved was 13 and the maximum score was 69 points. The first participant who reached $\mathrm{B} 2+$ level was a female whose English language course grade was an A. This participant stated that she listened to music, watched movies and read books in English, but did not have any additional English language classes and she also stated that she was neither satisfied nor dissatisfied with the teaching methods applied and the course book used in English classes. The second student who met the B2+ criteria was a male and he also achieved an A in the English language course. He stated that he sometimes listened to music in English, but always watched movies and read books in English. He also stated that he had not attended additional English language classes previously and expressed his satisfaction with the teaching methods and course book. When the remaining proficiency test results are taken into consideration, 21 participants achieved B1 and 18 participants $\mathrm{B} 1 / \mathrm{B} 2$ level and a considerable number of students $(\mathrm{N}=14)$ reached $\mathrm{A} 2$ level. In addition to that, there were also some participants $(\mathrm{N}=3)$ whose score indicated that they achieved only A1 English level proficiency level. The first participant whose proficiency was on A1 level achieved B in the English language course and stated that he read books, listened to music and watched movies in English and also had additional language classes. Another two participants who achieved A1 level, got C and B in the English language course and did not read books in English or attend additional English language classes. Moreover, they stated that they often listened to music and never watched movies without translation in English.

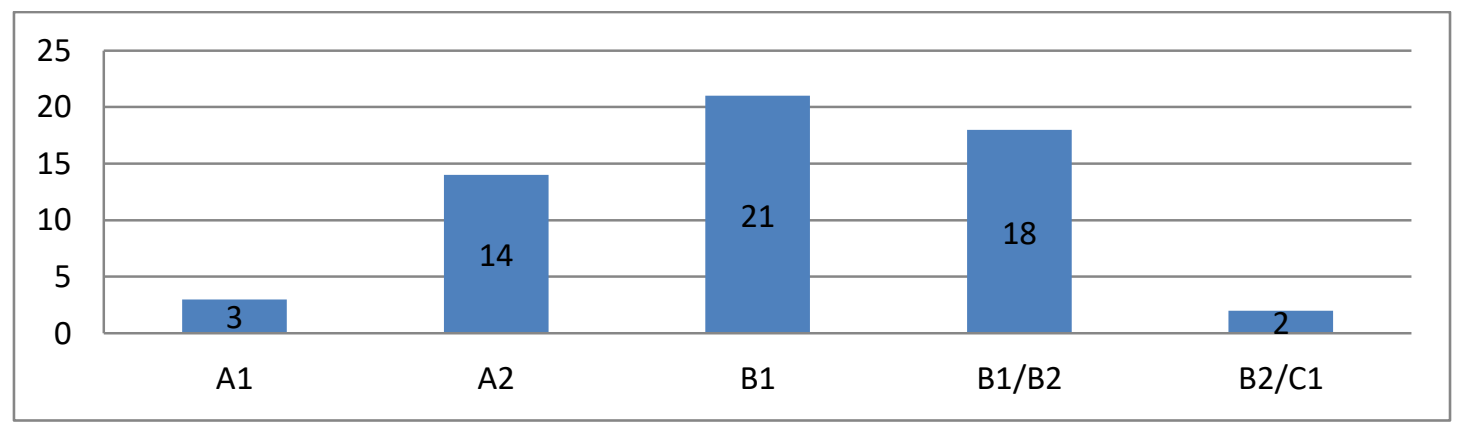

Fig. 1. English language proficiency level of the final-grade secondary-school students

Is there a significant correlation between students' proficiency test score and their English
language grade?
Secondly, Spearman correlation coefficient was computed to assess the relationship between
the students' proficiency test score $(M=41.59, S D=13.64)$ and their English language grade $(M=$
4.22, $S D=.68)$. The results showed that the correlation between the students' proficiency test
score and their English language grade was moderate and significant $\left(r_{s}=.47, p=\right.$. ooo $)$. In other
words, the Spearman correlation coefficient showed that the increase in the proficiency test score
correlates with the higher English language grade.
Is there a statistically significant difference between female and male students' English
language proficiency?
The next hypothesis tested whether any significant difference exists between female and male
students' English language proficiency. The results of the independent sample T-test showed that
no statistically significant difference was found in that respect. The results showed no significant
difference in the participants' English language proficiency $(t=-1.607, p=.124)$ between males 
$(M=45.40, S D=12.70)$ and females $(M=39.57, S D=13.85)$. These results suggest that the students' gender does not affect their English language proficiency. However, as can be observed in Table 3 below the male respondents $(M=45.40, S D=12.70)$ had an insignificantly higher mean in the proficiency test score than the female participants $(M=39.57, S D=13.85)$ (Table 3).

Table 3. T-test results comparing males and females' English language proficiency level

\begin{tabular}{lllll}
\hline Gender & $\mathrm{N}$ & Mean & SD & $p$ \\
\hline Female & 38 & 39.57 & 13.85 & \\
Male & 20 & 45.40 & 12.70 & .124 \\
\hline
\end{tabular}

Students' perceptions about the English language course in their school

When the students' perceptions are closely analysed, it can be noticed that most respondents believe that English needs to be more frequently used as the means of communication in the classroom and that a better rapport between students and professors needs to be established (see Table 4). Several respondents regretted the fact that the syllabus lacks lessons that can be applied to everyday situations and conversations. Likewise, the participants complained about the use of outdated teaching methods that include grammar learning without precise goals and objected to rather large class groups. Certainly, there were a few respondents who said they would not change anything in their English language course. Some of the comments are presented in Table 4.

Table 4. Students' opinions about English language course

Student 1: "Change the curriculum and syllabus as well as the way of the communication between the students and teachers."

Student 2: "Change the course book, the way of teaching and learning and finally put the focus on the speaking skill rather than boring grammar. We do not know the purpose of the grammar learning."

Student 3: "Increase the number of the projects and presentations so that students more participate and enhance their vocabulary and speaking skills."

Student 4: "Teachers should dedicate more time and effort to the students, especially in the speaking skill. Our homework could also be changed to watching movies in English and then discussing it in the class etc."

Student 5: "Teachers should focus more on our conversational skills and force us to read more literature in English".

\section{Discussion and conclusion}

This research study aimed to see whether the final-grade secondary-school students reached the B2+ level of English language proficiency by using the Full Placement Test. Moreover, it also aimed to investigate some other factors that might influence students' English language proficiency and their opinions. The first hypothesis stating that secondary school students are expected to reach B2+ level of English language proficiency at the end of their high school education was refuted as only 2 (4\%) out of 58 students reached this level. Since the proficiency test results ranged from A1 to the expected $\mathrm{B} 2+$, the assumption stating that there is usually a high discrepancy between the students' English language knowledge as well as their proficiency test results might be valid. These results are in line with Makewa et al.'s results (2013) which indicated that their participants' English language knowledge was average. Likewise, the present findings are in concordance with the research study conducted by Sijali (2017), which indicated that Nepali students achieved a very poor English language proficiency level. This hypothesis set different questions for discussion, and one of them asks for possible reasons for such poor results achieved at the ELL proficiency test by the students who have an excellent or a very good grade in their English language course. The answers to this question might be as follows: (1) the respondents 
were not motivated enough to do the test in the best way or (2) the respondents have high grades because their English language professors did not impose rather demanding requirements and thus the students did not have such advanced English language skills. Furthermore, one of the possible issues might be the learners' insufficient knowledge regarding the value of English as a foreign language and the possibility to use it in different domains. Finally, it is highly possible that the lack of intrinsic and extrinsic motivation, not clearly defined goals and benefits of learning English are related to the fact that English language learners have not achieved a satisfactory level at English language proficiency test.

The second hypothesis stating that there is a significant correlation between the students' English language proficiency and their English language grade was supported as a significant positive correlation at $\left(r_{s}=0.467, p=.000\right)$ was found between the English language grade $(\mathrm{M}=$ 4.22, $\mathrm{SD}=.68)$ and the students' English language proficiency $(M=41.59, S D=13.64)$. Such findings indicate that as the students obtain better English language grades they achieve better proficiency test results. This is in line with the findings presented in Racca and Lasaten (2016), which also showed that the correlation between the students' English language proficiency and their academic performance in English, mathematics, and science was significant.

The third hypothesis stating that there is no statistically significant difference between the female and male participants' English language proficiency was also supported. Despite the fact that the male participants achieved a moderately higher score than the female participants, that difference was insignificant. However, to some extent, these results diverge from those presented in Delić et al. (2018) in which a statistically significant difference was found between male and female students in the process of English language learning, with males achieving a slightly higher mean than females. On the other side, the obtained data were in concordance with the findings of Sijali (2017), which showed that the female participants achieved a lower proficiency mean than the male participants.

Finally, students were also asked about the quality of teaching the English language course in their school, and their answers suggested that they are not completely satisfied with it and that they would like some changes to be implemented, mostly in terms of the language usage in the classroom and the curriculum adaptation to the needs of regular wide ELL usage. More precisely, the majority of the participants were not satisfied with the teaching methods, they would like to have classes organized differently with more focus placed on speaking and reading skills instead of grammar and translation. However, there were some participants who said that they are satisfied with the English language course and that they would not like to change anything.

One of the limitations of this research is a small research sample so the results cannot be widely generalized. Thus, in order to get a better insight into this issue, a larger sample should be included as well as teachers who could also point to the difficulties that they encounter in the process of EFL teaching. In that way, one suggestion for future research might be to examine the possible causes of not fulfilling the requirements of English B2+ level in depth by taking into consideration all the current issues and challenges in teaching. All the obtained data can be used as a guideline in future EFL learning research in Bosnian high schools with the aim of improving it and focusing on having successful English language learners whose English language knowledge obtained in high schools might be an impetus for their future career.

\section{References}

Baidak, 2012 - Baidak, N., Borodankova, O., Kocanova, D., Motiejunaite, A. (2012). Key Data on Teaching Languages at School in Europe. 2012 Edition. Retrieved from http://ec.europa.eu/dgs/education_culture/repository/languages/policy/strategic-framework/ documents/key-data-2012_en.pdf

Bećirović, Podojak, 2018 - Bećirović, S., Podojak, S. (2018). Intercultural Development of Bosnian University Students Through Foreign Language Learning. European Researcher, 9(2), pp. 68-77.

Bećirović et al., 2017 - Bećirović, S., Brdarević Čeljo, A., Sinanović, J. (2017). The use of metacognitive reading strategies among students at international Burch university: A case study. European Journal of Contemporary Education, 6, pp. 645-655. 
Bećirović et al., 2018 - Bećirović, S., Brdarević-Čeljo, A., Dubravac, V. (2018). The Effect of Nationality, Gender, and GPA on the Use of Reading Strategies Among EFL University Students. SAGE open 8(4), pp. 1-12.

Brdarević-Čeljo, Asotić, 2017 - Brdarević-Čeljo, A., Asotić, M. (2017). The Influence of Social Context, Grade Level and Gender on the Use of Language Learning Strategies in Primary Schools. Imperial Journal of Interdisciplinary Research (IJIR), 3(12), 7-14.

Brown, 1994 - Brown, H.D. (1994). Principles of language learning and teaching. Englewood Cliffs: Prentice Hall Regents.

Common European Framework..., 2001 - Common European Framework of Reference for Languages: learning, teaching, assessment, 2001. Retrieved from https://rm.coe.int/1680459f97

Crystal, 1997 - Crystal, D. (1997). English as a global language. Cambridge: Cambridge University Press.

Crystal, 2003 - Crystal, D. (2003). English as a Global Language (Second edition).

Crystal, 2012 - Crystal, D. (2012). English as a global language. Cambridge university press.

Crystal, 2015 - Crystal, D. (2015). A world of languages and language houses. In Dürr, Michael, Doris Müller-Toovey\& Michael Vogt (eds.), Die Welt der Sprachen: NeueVermittlungsformatefür die AuseinandersetzungmitSprachlicherVielfalt, 106-114. Berlin: Zentral- und Landesbibliothek.

Delić et al., 2018 - Delić, H., Bećirović, S., Brdarević-Čeljo, A. (2018). Effects of grade level and gender on foreign language learning process in Bosnian high schools. International Journal Of Educational Policy Research And Review, 5(6). doi: 10.15739/ijeprr.18.010

Dornyei, 1994 - Dornyei, Z. (1994). Motivation and Motivating in the Foreign Language Classroom. The Modern Language Journal, 78(3), 273. doi:10.2307/330107

Habibić, Dubravac, 2016 - Habibić, A., Dubravac, V. (2016). Grammar Acquisition in Bosnian EFL Classrooms. Pismo. IV. 114-142.

Horwitz, 1987 - Horwitz, E.K. (1987). Surveying student beliefs about language learning. In A.Wenden,\& J. Rubin (Eds.), Learner strategies in language learning. Englewood Cliffs, NJ:Prentice-Hall.

Ivošević et al., 2013 - Ivošević, S., Sarajlić, D., Saračević, M., Pelko, A., Bogdanović, Z., Rahmanović, M., Curić, M. (2013). Evaluacija primjene nastavnih planova i programa u 5 porodica zanimanja u SSO BiH. Grafid, Banja Luka.

Krashen, 1987 - Krashen, S. (1987). Principles and practice in second language acquisition. New York: Phoenix ELT.

Lambert, Gardner, 1972 - Lambert, W., Gardner, R. (1972). Motivational variables in second language acquisition. In R. Gardner \& W. Lambert, Attitudes and motivation in second language learning.

Makewa et al., 2013 - Makewa, L., Role, E., Tuguta, E. (2013). Students' Perceived Level of English Proficiency in Secondary Schools in Dodoma, Tanzania.

Ministry of Education, 2016 - Ministry of Education. (2016). Nastavni plan i program. Srednjaškolazastručnoobrazovanjeiobuku. Četverogodišnji program. Predmet: Engleskijezik (I stranijezik). [The curriculum for vocational secondary schools. Four-year long programme. Subject: The English language (as the first foreign language)]. Retrieved from https://mon.ks.gov.ba/sites/mon.ks.gov.ba/files/engleski_jezik_srednje_skole_za_strucno_obr azovanje_i_obuku_-_cetvrti_stepen.pdf

Ortega, 2009 - Ortega, L. (2009). Understanding second language acquisition. Routledge, New York.

Racca, Lasaten, 2016 - Racca, R.M.A.B., Lasaten, R.C.S. (2016). English language proficiency and academic performance of Philippine science high school students. International Journal of Languages, Literature and Linguistics, 2(2), 44-49.

Rezultati eksterne..., 2013 - Rezultati eksterne mature 2012/13 (The Results of external testing 2012/2013). (2013). Retrieved from http://www.emis.edu.ba/post/2013/o6/21/rezultatieksterne-mature-za-2012-13.aspx

Rizvić, Bećirović, 2017 - Rizvić, E., Bećirović, S. (2017). Willingness to Communicate in English as a Foreign Language in Bosnian - Herzegovinian EFL Context, European Researcher. Series A International J. Soc. Sci. (8)3. 
Rost, 2006 - Rost, M. (2006). Generating Student Motivation. Retrieved from http://www.pearsonlongman.com/ae/worldview/motivation.pdf

Schütz, 2005 - Schütz, R. (2005). English-the international language. Retrieved April, 1, 2018, from http://www.sk.com.br/sk-ingl.html

Sijali, 2017 - Sijali, K. (2017). English language proficiency level of Higher Secondary level students in Nepal. Journal Of Advanced Academic Research, 3(1), 59.

Simons, Charles, 2018 - Simons, Gary F., Charles D. Fennig (eds.). (2018). Ethnologue: Languages of the World, Twenty-first edition. Dallas, Texas: SIL International. Online version: http://www.ethnologue.com

Tankosic, Dubravac, 2016 - Tankosic, A., Dubravac, V. (2016). The assessment of Bosnian EFL learners' knowledge by two different measures: test and writing assignment. ExELL. 4. 10.1515/exell-2017-0006. 